\title{
Green materials science and engineering reduces biofouling: approaches for medical and membrane-based technologies
}

\author{
Kerianne M. Dobosz ${ }^{\dagger}$, Kristopher W. Kolewe ${ }^{\dagger}$ and Jessica D. Schiffman * \\ Department of Chemical Engineering, University of Massachusetts Amherst, Amherst, MA, USA
}

OPEN ACCESS

Edited by:

Bradley M. Tebo,

Oregon Health and Science

University, USA

Reviewed by:

John W. Moreau,

University of Melbourne, Australia

James F. Holden,

University of Massachusetts Amherst,

USA

*Correspondence:

Jessica D. Schiffman,

Department of Chemical Engineering, University of Massachusetts Amherst, N540D Life Sciences Laboratories,

240 Thatcher Road, Amherst,

MA 01003-9364, USA

schiffman@ecs.umass.edu

${ }^{\dagger}$ These authors have contributed

equally to this work.

Specialty section:

This article was submitted to

Microbiological Chemistry and

Geomicrobiology, a section of the

journal Frontiers in Microbiology

Received: 28 November 2014

Paper pending published:

04 January 2015

Accepted: 23 February 2015

Published: 17 March 2015

Citation:

Dobosz KM, Kolewe KW and Schiffman JD (2015) Green materials science and engineering reduces biofouling: approaches for medical and membrane-based technologies.

Front. Microbiol. 6:196.

doi: 10.3389/fmicb.2015.00196
Numerous engineered and natural environments suffer deleterious effects from biofouling and/or biofilm formation. For instance, bacterial contamination on biomedical devices pose serious health concerns. In membrane-based technologies, such as desalination and wastewater reuse, biofouling decreases membrane lifetime, and increases the energy required to produce clean water. Traditionally, approaches have combatted bacteria using bactericidal agents. However, due to globalization, a decline in antibiotic discovery, and the widespread resistance of microbes to many commercial antibiotics and metallic nanoparticles, new materials, and approaches to reduce biofilm formation are needed. In this mini-review, we cover the recent strategies that have been explored to combat microbial contamination without exerting evolutionary pressure on microorganisms. Renewable feedstocks, relying on structure-property relationships, bioinspired/nature-derived compounds, and green processing methods are discussed. Greener strategies that mitigate biofouling hold great potential to positively impact human health and safety.

Keywords: antibiotic resistance, antifouling, biofouling, green chemistry, resistance genes, drug development

\section{Introduction}

Biofilms are communities of aggregated microorganisms surrounded by a self-produced matrix of extracellular polymeric substances. Across industries, including, healthcare, food production, and membrane-based separation processes, biofilms yield detrimental results (Baker and Dudley, 1998; Van Houdt and Michiels, 2010). Within the clinical setting, bacterial colonization, and subsequent biofilm formation is a pressing challenge that leads to chronic infections (Flemming and Wingender, 2010). Foodborne illnesses associated with bacterial contamination during food processing yield enhanced tolerance to antibiotic treatments (da Silva and De Martinis, 2013). Once fouled, the lifetime, and performance of membranes are significantly decreased, which leads to monetary and health ramifications. Prevention of bacteria attachment is the most effective method of preventing disease, reducing operational costs, and saving energy.

In membrane-based technologies, one approach to eliminate biofouling is to attach biocidal nanomaterials, including silver (Mauter et al., 2011), copper (Dasari et al., 2012), selenium (Akar etal., 2013), and titanium dioxide to the surface of a membrane. To inactivate microbes, commercial antibacterial agents have been released from polymer 
medical devices (Nget al., 2013). However, these approaches yield concerns related to the antibacterial agent release rate, depletion, and toxicity to human cells (Schiffman and Elimelech, 2011). Furthermore, the widespread resistance of microbes toward antimicrobials underscores the importance of developing alternative strategies that mitigate the initial attachment of bacteria without exerting evolutionary pressure. Ultrafiltration (UF) membrane surface chemistry plays a role in their propensity to foul. Commercial UF membranes are fabricated from inexpensive, hydrophobic polymers-polysulfone (PSf), polyethersulfone, polypropylene, or polyvinylidene chloride. While these membranes provide proper mechanical and chemical stability, they suffer from biofouling.

In this mini-review, we discuss the benefits of engineering biopolymers and cover recent strategies from medical and membrane-based technologies that have been reported to combat microbial contamination with less evolutionary pressure on microorganisms, meaning that bacteria have shown less resistance to these greener approaches. Biopolymers, surface topography, nature-derived antimicrobials, and green processing are discussed. These green strategies hold great potential to positively impact human health and safety.

\section{Starting With Greener Polymers}

Biopolymers are polymers derived from naturally occurring matter such as crustacean shells, mushrooms, or wood. In addition to being sustainable, biopolymers also offer inherent properties such as, antibacterial activity, biodegradability, biocompatibility, chelation, and coagulation capabilities (Schiffman and Schauer, 2008). One example is chitin and its deacetylated derivative chitosan, which have been heavily investigated for wound healing scaffolds due to their biocompatibility and cationic amine groups, which provide antibacterial activity (Kong et al., 2010). However, working with biopolymers can introduce complications. Chitin can be extracted from a wide number of natural sources including crustacean shells, insect cuticles, and fungal biomass (Schiffman and Schauer, 2009; Hajji et al., 2014). Based on the source, the extracted chitin will vary in molecular weight, degree of deacetylation, purity, distribution of charged groups, and crystallinity. While natural variability can complicate controlled manufacturing, the intrinsic benefits cannot be overlooked. For this reason biopolymers derived from natural feedstocks including, chitin, pectin, cellulose, gelatin, and alginate, have been investigated for biomedical and environmental technologies (Lee and Mooney, 2012; Kalia et al., 2013; Birch and Schiffman, 2014).

\section{Green Materials Science and Engineering for Biomedical Applications}

As noted previously, biopolymers offer intrinsic functionality and biocompatibility making them ideal hydrogel tissue engineering scaffolds (Van Vlierberghe et al., 2011). Biodegradable polymers, including, polylactic acid, polycaprolactone, and poly-alhylcyanoacrylates are used for temporary therapeutics and drug delivery vehicles that limit biofouling, while maintaining biocompatibility (Kumari et al., 2010). Numerous other review articles discuss polymers for biomedical implants, here we focus on alternative strategies that could potentially be used synergistically with polymeric medical devices to decrease bacterial contamination.

\section{Greener Antifouling and Antibacterial Surfaces}

Antimicrobial materials kill microbes through passive contact with functionalized cationic/biomolecule groups or via interactions with released antimicrobial compounds (Isquith et al., 1972; Ouattara et al., 2000). In an effort to move away from antimicrobials that cause evolutionary pressure on microorganisms, the targeting specificity of cationic peptides have demonstrated excellent potential in disrupting biofilms (Hofmann et al., 2012). Plant derivatives are ideal candidates for active antibacterial agents (Burt, 2004). Due to the polydispersity of essential oils - carvacrol, cinnamaldehyde (Zodrow et al., 2012), green tea (Reygaert, 2014) - they do not exhibit bacterial resistance. The small volatile molecules have been delivered via carrier-solutions, polymer derivatives, or encapsulated in solid particles/films (Kavanaugh and Ribbeck, 2012; Zodrow et al., 2012; Badawy and Rabea, 2013; Carbone-Howell et al., 2015; Rieger et al., 2015). Recently, we have demonstrated the ability to incorporate essential oils into biopolymer nanofiber mats (Rieger and Schiffman, 2014) and ultra-thin films (Rieger et al., 2015). In time dependent cytotoxicity studies on the biopolymer nanofibers, the intrinsic antibacterial activity of chitosan along with the quick release of cinnamaldehyde from the nanofibers enabled high inactivation rates against Escherichia coli and Pseudomonas aeruginosa (Rieger and Schiffman, 2014).

Antifouling surfaces prevent the adhesion of microbes and proteins to surfaces via super hydrophobic or hydrophilic properties (Keefe et al., 2012). Polyethylene glycol (PEG) is a preeminent polymer for biomedical applications (Langer and Tirrell, 2004) because the biocompatible polymer forms a hydration layer with the surrounding environment to provide non-specific antifouling ability. However, PEG-based materials oxidize after exposure to physiological environments, thus limiting their long term effectiveness. Another class of non-fouling polymers that have a broader chemical diversity are zwitterionic polymers, which offer positive and negative charges on a single monomer (polybetaines), or different monomers (polyampholytes) (Chen et al., 2010).

\section{Topographic Cues and Substrate Stiffness Influence Microbial Behavior}

Surface topography has been proposed as a non-toxic surface modification to reduce bacterial adhesion (Hoffman, 2002; Engel et al., 2012; Rizzello et al., 2013; Harding and Reynolds, 2014). Table 1 summarizes recent investigations into the effect that microscale topography has on biofilm development. Nanotopographic patterning or biomimetic surfaces can also limit bacterial adhesion (Scardino and de Nys, 2011). For example, independent of feature dimensions (square, rectangular, or 
TABLE 1 | Microorganisms respond to surface topography. Schematics of the topographies are provided, as well as highlighted examples with figures reprinted (adapted) with permission from the American Chemical Society. The dimensions given include length (I), width (w), height (h), diameter (d), and interspatial spacing (s). All substrates are polydimethylsiloxane (PDMS) except for the parallel fibers.

\begin{tabular}{|c|c|c|c|c|}
\hline & & Dimensions & Microorganism(s) & Reference(s) \\
\hline \multirow{3}{*}{ 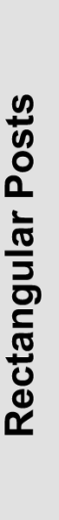 } & & $\begin{array}{l}\mathrm{h}=3 \mu \mathrm{m} ; \mathrm{s}=2 \\
\mu \mathrm{m} ; \mathrm{L}=4-16 \\
\mu \mathrm{m} ; \mathrm{w}=2 \mu \mathrm{m}\end{array}$ & S. aureus & (Chung et al. 2006) \\
\hline & W & $\begin{array}{l}h=1 \mu \mathrm{m} ; s=2 \\
\mu \mathrm{m} ; \mathrm{w}=2.2 \mu \mathrm{m}\end{array}$ & $\begin{array}{l}\text { Neisseria } \\
\text { gonorrhoeae; } \\
\text { Myxococcus } \\
\text { xanthus }\end{array}$ & (Meel et al. 2012) \\
\hline & \multicolumn{4}{|c|}{$\begin{array}{l}\text { Highlighted Example: Rectangular posts }(\mathrm{h}=3 \\
\mu \mathrm{m} ; \mathrm{s}=3 \mu \mathrm{m} ; \mathrm{L}=2 \mu \mathrm{m} ; \mathrm{w}=3 \mu \mathrm{m} \text { ) significantly } \\
\text { reduced } S \text {. epidermis, } B \text {. subtilis, } E \text {. coli } \\
\text { adhesion independent of pattern shape or } \\
\text { bacterial strain (Perera-Costa et al. } 2014)^{\dagger} \text {. }\end{array}$} \\
\hline \multirow{2}{*}{ 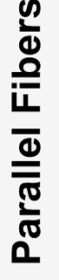 } & $\stackrel{L}{\longrightarrow}$ & $\begin{array}{l}\mathrm{d}=70-1100 \mathrm{~nm} \\
\mathrm{~s}=<100 \mathrm{~nm}\end{array}$ & $P$. aeruginosa & (Kargar et al. 2012) \\
\hline & \multicolumn{4}{|c|}{$\begin{array}{l}\text { Highlighted Example: Aligned polystyrene fibers limited the surface binding sites available for } \\
\text { bacteria while increasing the cost of deformation (Kargar et al. 2012). }\end{array}$} \\
\hline \multirow{3}{*}{ 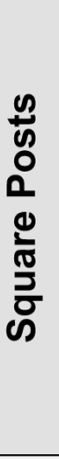 } & & $\begin{array}{l}\mathrm{h}=3 \mu \mathrm{m} ; \mathrm{s}=4 \\
\mu \mathrm{m} ; \mathrm{L}=6 \mu \mathrm{m}\end{array}$ & $\begin{array}{l}\text { S. epidermidis; } \\
\text { B. subtilis; E. coli }\end{array}$ & $\begin{array}{l}\text { (Perera-Costa et al. } \\
\text { 2014) }\end{array}$ \\
\hline & h & $\begin{array}{l}h=-1 \mu \mathrm{m} ; s=2 \\
\mu \mathrm{m} ; L=0.6\end{array}$ & $\begin{array}{l}\text { Neisseria } \\
\text { gonorrhoeae; } \\
\text { Myxococcus } \\
\text { xanthus }\end{array}$ & (Meel et al. 2012) \\
\hline & \multicolumn{4}{|c|}{$\begin{array}{l}\text { Highlighted Example: Square posts }(\mathrm{h}=10 \mu \mathrm{m} ; \mathrm{s}=5,10,15,20 \mu \mathrm{m} ; \mathrm{L}=2,5,10,15,20,30,40,50 \text {, } \\
100 \mu \mathrm{m}) \text { exhibit reduced adhesion of } E \text {. coli compared to flat surfaces. Independent of gravity, the } \\
\text { spatial distribution of adhered bacteria was preferential in the recesses, until a critical limit pillar size } \\
\text { was reached (Hou et al. 2011). }\end{array}$} \\
\hline \multirow{2}{*}{ 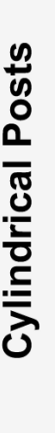 } & & $\begin{array}{l}h=3 \mu \mathrm{m} ; s=2 \\
\mu \mathrm{m} ; \mathrm{d}=3 \mu \mathrm{m}\end{array}$ & $\begin{array}{l}\text { S. epidermis; } \\
\text { B. subtilis; E. coli }\end{array}$ & $\begin{array}{l}\text { Perera-Costa et al. } \\
\text { 2014) }\end{array}$ \\
\hline & \multicolumn{4}{|c|}{$\begin{array}{l}\text { Highlighted Example: By confining microbes ( } P \text {. aeruginosa, } B \text {. } \\
\text { subtilis, } E \text {. coli) in spaces similar to their size, cell adhesion and } \\
\text { early biofilm development were controlled. Cylinders }(h=2 \mu \mathrm{m} \text {; } \\
\mathrm{s}=0.7,0.9,1.2 \mu \mathrm{m} ; \mathrm{d}=300 \mathrm{~nm} \text { ) were used (Hochbaum and } \\
\text { Aizenberg } 2010) . \neq\end{array}$} \\
\hline
\end{tabular}

${ }^{\dagger}$ Reprinted (adapted) with permission from Perera-Costa et al. (2014), Copyright (2014) American Chemical Society.

${ }^{\ddagger}$ Reprinted (adapted) with permission from Hochbaum and Aizenberg (2010), Copyright (2010) American Chemical Society. 
circular posts), it was reported (Perera-Costa et al., 2014) that organized topography significantly reduces bacterial attachment. Engineered roughness index has been proposed as a possible explanation for the reduction of microbial adhesion, however, the general mechanism remains poorly understood (Bazaka et al., 2011).

Substrate stiffness is a tunable material property that limits bacterial adhesion without inducing resistance development (Lichter et al., 2008). Effective stiffness was utilized in a polydimethylsiloxane (PDMS) nanoarray to control the spatial organization of $P$. aeruginosa around compliant nanoposts (Epstein et al., 2011).

\section{Green Materials Science and Engineering for Membrane-based Technologies}

\section{Bio-inspired Membrane Modifications Reduce Biofouling}

During the standard membrane operation, microbes, or macromolecules in the feed solution components accumulate on the surface of the membrane, which leads to retardation of flux and loss of performance, as shown in Figure 1. Table 2 provides a schematic of this phenomena called biofouling, as well as highlights green strategies to minimize biofouling. Previous reviews have covered the traditional approaches employed to reduce biofouling on membranes, including the use of synthetic polymers and metallic ions (Baker and Dudley, 1998; Kumar and Anand, 1998; Mansouri et al., 2010; Perera et al., 2014). In general, the membrane field could also look toward greener approaches being tested in the medical and food industries to combat biofouling (Simoes et al., 2010; Cappitelli et al., 2014).

Numerous recent reports have explored the use of biopolymers to reduce biofouling in membrane-based separations. Cellulose acetate nanofiltration membranes surface modified with sodium alginate and chitosan showed a $15 \%$ flux increase when challenged with bovine serum albumin (BSA) (Lajimi et al., 2011). Higher permeability was achieved by blending $N$-succinyl chitosan into UF membranes (Kumar et al., 2013a). Membranes with $N$-propylphosphonic chitosan added to their surface exhibited higher permeability and antifouling properties over pristine PSf membranes (Kumar et al., 2013b). Exploring advantageous charges, $N$-carboxymethyl chitosan and $\mathrm{O}$-carboxymethyl chitosan-based amphoteric or $\mathrm{pH}$ responsive charged membranes were prepared for protein separation. It was reported that even after 50-days of operation in a protein environment there was no membrane fouling (Chakrabarty and Shahi, 2014). Recently, the addition of layerby-layer films of chitosan and carboxymethyl cellulose to partially deacetylated cellulose acetate films yielded a 55\% reduction in BSA adsorption (Mohan et al., 2015).

Polydopamine (PDA) is a bio-inspired polymer that mimics the adhesion secretions of mussels (Brubaker and Messersmith, 2012). The self-polymerizing polymer is capable of anchoring to and protecting surfaces from microbial contamination (Lee et al., 2007; Dreyer et al., 2012). PSf UF membranes and commercial polyamide (PA) reverse osmosis (RO) membranes modified with PDA exhibited an increase in antifouling properties (Kasemset et al., 2013; Miller et al., 2014). Additional research with PSf UF membranes includes coating the membranes with dopamine methacrylamide and a plant-based methacrylate, which showed higher biofouling resistance and bactericidal properties than the control membranes (Choi et al., 2014). Due to their larger pore size, flux was maintained after coating PDA on poly(vinylidene fluoride, $\mathrm{PVDF}$ ) microfiltration (MF) membranes, as opposed to a similar modification conducted on RO and UF membranes (McCloskey et al., 2010). PDA coatings have increased the rejection during oil/water emulsion separations (McCloskey et al., 2012) and improved the mechanical properties and hydrophilicity of electrospun nanofiber membranes for filtration applications (Huang et al., 2014).

Biological molecules have also been explored to improve membrane properties. This includes attaching serine protease to the surface of cellulose acetate UF membranes, which resulted in a relative flux reduction ratio of $97-88 \%$, along with an increase in steady state flux from 8 to $34 \mathrm{~L} \mathrm{~m}^{-2} \mathrm{~h}^{-1}$ for the pristine and treated membranes, respectively (Koseoglu-Imer, 2013). Polyethersulfone UF membranes surface modified with myoglobin increased membrane hydrophilicity by $47.13 \%$ and lysozome rejection by $21.43 \%$ (Ali and Tari, 2012). The surface of chloromethylated PSf membranes modified with gluconolactone had improved anti-protein adsorption ability (Fan et al., 2012). The body of PSf membranes were blended with a ternary

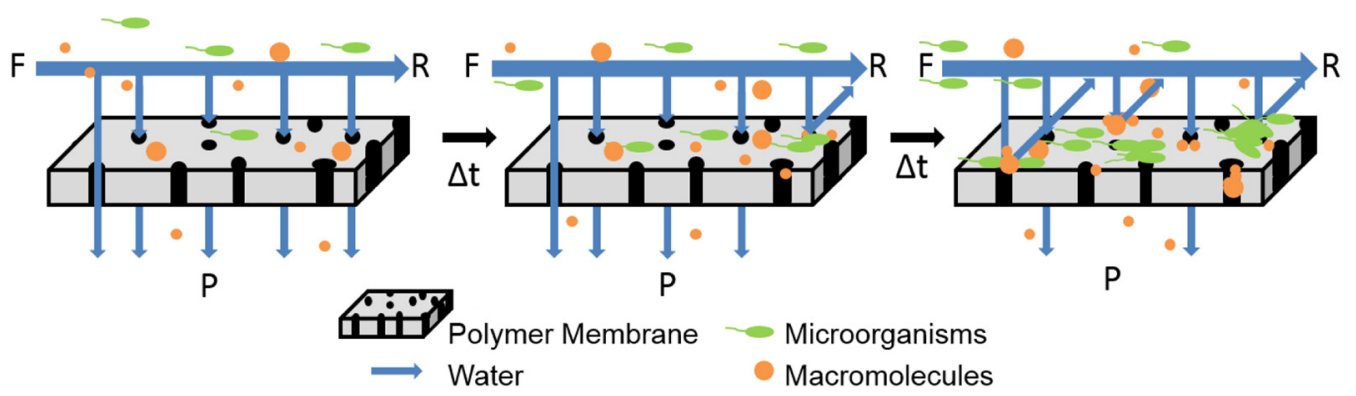

FIGURE 1 | Schematic illustrates that membranes become fouled when operated in cross-flow systems with constant flow and pressure. Direction of feed $(F)$, retentate $(R)$, and permeate $(P)$ are provided. 
TABLE 2 | This table highlights recent publications that have investigated green modifications to microfiltration, ultrafiltration, and reverse osmosis membranes.

\begin{tabular}{|c|c|c|}
\hline Modification(s) and Membrane & Effect(s) & Reference \\
\hline $\begin{array}{l}\text { Capsaicin derivatives blended into membrane body or } \\
\text { surface modification on UF PSF membranes. }\end{array}$ & $\begin{array}{l}\text { Increased water flux in blended membrane, increased flux, antifouling } \\
\text { and antibacterial properties when challenged by humic acid. }\end{array}$ & $\begin{array}{l}\text { Xu et al. (2013), Wang et al. } \\
(2014)\end{array}$ \\
\hline $\begin{array}{l}N \text {-succinyl or } N \text {-propylphosphonic chitosan blended } \\
\text { into UF PSf membranes. }\end{array}$ & $\begin{array}{l}\text { Increased hydrophilicity, flux, and fouling resistance ratio when } \\
\text { challenged with bovine serum albumin (BSA). }\end{array}$ & Kumar et al. $(2013 a, b)$ \\
\hline $\begin{array}{l}\text { } \text {-Gluconolactone surface modification on } \\
\text { chloromethylated UF PSf membranes. }\end{array}$ & $\begin{array}{l}\text { Increased human serum albumin rejection from } 84 \pm 1 \% \text { to } 96 \pm 1 \% \text {. } \\
\text { Increased pure water flux resistance by } 14 \% \text {. }\end{array}$ & Fan et al. (2012) \\
\hline Lysozyme surface modification on PA RO membranes. & $\begin{array}{l}\text { Increased water flux resistance, antibacterial activity against } \\
\text { Gram-positive bacteria, and antifouling properties. }\end{array}$ & Saeki et al. (2013) \\
\hline $\begin{array}{l}\text { Myoglobin surface modification on UF polyethersulfone } \\
\text { membranes. }\end{array}$ & $\begin{array}{l}\text { Increased hydrophilicity and increased lysozyme rejection by up to } \\
21.43 \% \text {. }\end{array}$ & Ali and Tari (2012) \\
\hline PDA surface modification on MF PVDF membranes. & $\begin{array}{l}\text { Increased organic rejection. Flux persisted from pristine to modified } \\
\text { membrane. }\end{array}$ & McCloskey et al. $(2010,2012)$ \\
\hline $\begin{array}{l}\text { PDA, PDA-graft-PEG, and PDA co-polymers surface } \\
\text { modification on UF PSf membranes. }\end{array}$ & $\begin{array}{l}\text { Increased antifouling efficiency and increased flux transmembrane } \\
\text { pressure when challenged with soybean emulsions, BSA, and oil. }\end{array}$ & $\begin{array}{l}\text { Choi et al. (2014), Miller et al. } \\
\text { (2014) }\end{array}$ \\
\hline $\begin{array}{l}\text { PDA surface modification on thin-film composite RO } \\
\text { membranes. }\end{array}$ & $\begin{array}{l}\text { Increased pure water resistance with increasing PDA. Increased flux } \\
\text { during oil/water separations. }\end{array}$ & Kasemset et al. (2013) \\
\hline
\end{tabular}

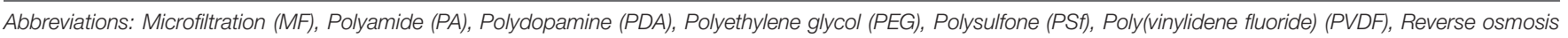
(RO), Ultrafiltration (UF).

copolymer having capsaicin-mimic moieties improved the permeate flux and rejection when challenged by a humic acid solution and a seawater solution; excellent antibacterial efficiency was also reported (Xu et al., 2013). Capsacin grafted to the surface PSf membranes demonstrated improved antifouling and antibacterial properties (Wang et al., 2014). RO membranes surface modified with lysozyme showed sufficient antibacterial activity against the Gram-positive bacteria, Micrococcus lysodeikticus, and Bacillus subtilis (Saeki et al., 2013). When heparin was attached to the surface of chitosan/cellulose acetate membranes they demonstrated antifouling characteristics, but not antibiofouling (Liu et al., 2010). The essential oil, cinnamaldehyde, was released for $\sim 2$ days whereas kanamycin was released for $\sim 80 \mathrm{~h}$ from the surface of RO membranes via biodegradable poly (lactic-co-glycolic acid) particles (Zodrow et al., 2014). However, a significant reduction in biofilm development was only observed on membranes modified with kanamycin capsules. Smaller size molecules, acids have been incorporated into membranes. By adsorbing citric acid onto the surface of UF PSf membranes, PEG rejection, BSA rejection, and flux recovery ratios increased (Wei et al., 2012). PSf membranes with the addition of ascorbic acid, citric acid, and malic acid into the body of membrane reported a superior pure water flux and higher permeation and rejection compared to control membranes (Ghaemi et al., 2012).

\section{Greener Solvents can Improve Membrane Properties}

Improvements to the membrane fabrication process have recycled and reduced the amount of noxious and waste solvent. In an effort to replace the flammable, toxic, and teratogenic membrane-casting solvents, dimethylformamide, and dimethyl sulfoxide, the use of non-toxic, non-flammable, and inexpensive supercritical carbon dioxide has been investigated
(Barroso et al., 2011). Polyacrylonitirile graft polyethylene oxide membranes cast using supercritical carbon dioxide exhibited an increase in hydrophilicity, larger protein/starch permeability, and an increased resistance to fouling (Barroso et al., 2011). Additionally, antifouling membranes have been synthesized using a solvent-free approach wherein 2-hydroxyethyl methacrylate was bulk polymerized. The homogenous membranes rejected 97 and 99\% of yeast and oil, respectively, (Peng et al., 2013). The easily recoverable ionic liquid 1-ethyl3-methylimidazolium acetate was used to produce cellulose and chitin active layers. When the bioactive coatings were applied to the surface of electrospun non-woven substrates, a similar rejection paired with a 10 -fold increase in permeation flux was reported in comparison to commercial UF membranes (Ma et al., 2011).

\section{Perspective}

Bacteria colonization and biofilm formation are pressing challenges that yield infections, higher energy consumption, and subsequent costs. New, innovative, and green solutions that mitigate these detrimental effects in medical and membranebased technologies without exerting evolutionary pressure on microbes or on our environment are needed. The intrinsic properties of historically employed biopolymers, naturally derived antimicrobials, and bio-inspired agents can improve the surface hydrophilicity, protein adhesion resistance, and antibacterial activity of materials. However, the long-term viability of surfaces that have been modified with chemical antimicrobials is often limited by microbial and solution surface conditioning. Namely, ions and proteins adsorb onto the surface and mask the surface activity (Palmer et al., 2007). Perhaps an "even greener" method than using biopolymers to create an antifouling surfaces is to avoid chemicals and employ a structure-property relationship. 
While organized topography certainly influences microbial behavior, virtually all examples from literature use PDMS. Further effort is needed to elucidate whether structure is a universal effect across all hard and soft surfaces. Incorporating spatially organized topography to medical implants and membranes, potentially, can be synergistically employed with non-specific antimicrobial compounds to extend surface functionality. With economy of scale, many of the same approaches employed to decrease biofouling on high-value biomedical devices may be appropriate for separation membranes. In the future, green materials science and engineering strategies that mitigate biofouling

\section{References}

Akar, N., Asar, B., Dizge, N., and Koyuncu, I. (2013). Investigation of characterization and biofouling properties of PES membrane containing selenium and copper nanoparticles. J. Membr. Sci. 437, 216-226. doi: 10.1016/j.memsci.2013.02.012

Ali, N., and Tari, S. S. M. (2012). Surface modification of polyethersulfone ultrafiltration (PES-UF) membrane using myoglobin as modifying agent. Desalin. Water Treat. 47, 171-181. doi: 10.1080/19443994.2012.696820

Badawy, M. E. I., and Rabea, E. I. (2013). Synthesis and structure-activity relationship of $\mathrm{N}$-(cinnamyl) chitosan analogs as antimicrobial agents. Int. J. Biol. Macromol. 57, 185-192. doi: 10.1016/j.ijbiomac.2013.03.028

Baker, J. S., and Dudley, L. Y. (1998). Biofouling in membrane systems - a review. Desalination 118, 81-89. doi: 10.1016/S0011-9164(98)00091-5

Barroso, T., Temtem, M., Casimiro, T., and Aguiar-Ricardo, A. (2011). Antifouling performance of poly(acrylonitrile)-based membranes: from green synthesis to application. J. Supercrit. Fluid 56, 312-321. doi: 10.1016/j.supflu.2010.10.035

Bazaka, K., Crawford, R. J., and Ivanova, E. P. (2011). Do bacteria differentiate between degrees of nanoscale surface roughness? Biotechnol. J. 6, 1103-1114. doi: 10.1002/biot.201100027

Birch, N. P., and Schiffman, J. D. (2014). Characterization of self-assembled polyelectrolyte complex nanoparticles formed from chitosan and pectin. Langmuir 30, 3441-3447. doi: 10.1021/la500491c

Brubaker, C. E., and Messersmith, P. B. (2012). The present and future of biologically inspired adhesive interfaces and materials. Langmuir 28, 2200-2205. doi: $10.1021 / \mathrm{la} 300044 \mathrm{v}$

Burt, S. (2004). Essential oils: their antibacterial properties and potential applications in foods-a review. Int. J. Food Microbiol. 94, 223-253. doi: 10.1016/j.ijfoodmicro.2004.03.022

Cappitelli, F., Polo, A., and Villa, F. (2014). Biofilm formation in food processing environments is stillpoorly understood and controlled. Food Eng. Rev. 6, 29-42. doi: 10.1007/s12393-014-9077-8

Carbone-Howell, A. L., Stebbins, N. D., and Uhrich, K. E. (2015). Poly(anhydrideesters) comprised exclusively of naturally occurring antimicrobials and EDTA: antioxidant and antibacterial activities. Biomacromolecules 15, 1889-1895. doi: $10.1021 / \mathrm{bm} 500303 \mathrm{a}$

Chakrabarty, T., and Shahi, V. (2014). Modified chitosan-based, pHresponsive membrane for protein separation. RSC Adv. 4, 53245-53252. doi: 10.1039/C4RA05314A

Chen, S., Li, L., Zhao, C., and Zheng, J. (2010). Surface hydration: principles and applications toward low-fouling/non-fouling biomaterials. Polymer 51, 5283-5293. doi: 10.1016/j.polymer.2010.08.022

Choi, Y., Kang, H., Kim, D., Cha, S., and Lee, J. (2014). Mussel-inspired dopamine and plant-based cardanol-containing polymer coatings for multifunctional filtration membranes. ACS Appl. Mater. Interfaces 6, 21297-21307. doi: $10.1021 / \mathrm{am} 506263 \mathrm{~s}$

Chung, J., Nerenberg, R., and Rittmann, B. E. (2006). Bio-reduction of soluble chromate using a hydrogen-based membrane biofilm reactor. Water Res. 40, 1634-1642. doi: 10.1016/j.watres.2006.01.049

da Silva, E. P., and De Martinis, E. C. P. (2013). Current knowledge and perspectives on biofilm formation: the case of Listeria monocytogenes. Appl. Microbiol. Biotechnol. 97, 957-968. doi: 10.1007/s00253-012-4611-1 will allow us to overcome current challenges to positively impact human health.

\section{Acknowledgments}

This work was partially supported by an NSF-BRIGE (EEC1342343) grant, the National Research Service Award T32 GM008515 from the National Institutes of Health, the James M. Douglas Career Development Faculty Award, and the Armstrong Fund for Science.

Dasari, A., Quirós, J., Herrero, B., Boltes, K., García-Calvo, E., and Rosal, R. (2012). Antifouling membranes prepared by electrospinning polylactic acid containing biocidal nanoparticles. J. Memb. Sci. 405-406, 134-140. doi: 10.1016/j.memsci.2012.02.060

Dreyer, D. R., Miller, D. J., Freeman, B. D., Paul, D. R., and Bielawski, C. W. (2012). Elucidating the structure of poly(dopamine). Langmuir 28, 6428-6435. doi: 10.1021/la204831b

Engel, Y., Schiffman, J. D., Goddard, J. M., and Rotello, V. M. (2012) Nanomanufacturing of biomaterials. Mater. Today 15, 478-485. doi: 10.1016/S1369-7021(12)70217-1

Epstein, K., Hochbaum, I., Kim, P., and Aizenberg, J. (2011). Control of bacterial biofilm growth on surfaces by nanostructural mechanics and geometry. Nanotechnology 22, 494007. doi: 10.1088/0957-4484/22/49/494007

Fan, H., Wang, C., Li, Y., and Wei, Y. (2012). Preparation and anti-protein fouling property of $\delta$-gluconolactone-modified hydrophilic polysulfone membranes. J. Membr. Sci. 415-416, 161-167. doi: 10.1016/j.memsci.2012.04.047

Flemming, H.-C., and Wingender, J. (2010). The biofilm matrix. Nat. Rev. Microbiol. 8, 623-633. doi: 10.1038/nrmicro2415

Ghaemi, N., Madaeni, S., Alizadeh, A., Daraei, P., Badieh, M., Falsafi, M., et al. (2012). Fabrication and modification of polysulfone nanofiltration membrane using organic acids: morphology, characterization and performance in removal of xenobiotics. Sep. Purif. Technol. 96, 214-228. doi: 10.1016/j.seppur.2012.06.008

Hajji, S., Younes, I., Ghorbel-Bellaaj, O., Hajji, R., Rinaudo, M., Nasri, M., and Jellouli, K. (2014). Structural differences between chitin and chitosan extracted from three different marine sources. Int. J. Biol. Macromol. 65, 298-306. doi: 10.1016/j.ijbiomac.2014.01.045

Harding, J. L., and Reynolds, M. M. (2014). Combating medical device fouling. Trends Biotechnol. 32, 140-146. doi: 10.1016/j.tibtech.2013.12.004

Hochbaum, A. I., and Aizenberg, J. (2010). Bacteria pattern spontaneously on periodic nanostructure arrays. Nano. Lett. 10, 3717-3721. doi: 10.1021/nl102290k

Hoffman, A. S. (2002). Hydrogels for biomedical applications. Adv. Drug Deliv. Rev. 64, 18-23. doi: 10.1016/j.addr.2012.09.010

Hofmann, C. M., Bednar, K. J., Anderson, J. M., and Marchant, R. E. (2012). Disruption of Staphylococcus epidermidis biofilm formation using a targeted cationic peptide. J. Biomed. Mater. Res. A 100, 1061-1067. doi 10.1002/jbm.a.33273

Hou, S., Gu, H., Smith, C., and Ren, D. (2011). Microtopographic patterns affect Escherichia coli biofilm formation on poly(dimethylsiloxane) surfaces. Langmuir 27, 2686-2691. doi: 10.1021/la1046194

Huang, L., Arena, J. T., Manickam, S. S., Jiang, X., Willis, B. G., and McCutcheon, J. R. (2014). Improved mechanical properties and hydrophilicity of electrospun nanofiber membranes for filtration applications by dopamine modification. J. Memb. Sci. 460, 241-249. doi: 10.1016/j.memsci.2014. 01.045

Isquith, A. J., Abbott, E. A., and Walters, P. A. (1972). Surface-bonded antimicrobial activity of an organosilicon quaternary ammonium chloride. Appl. Microbiol. 24, 859-863. doi: 10.1016/j.memsci.2014.01.045

Kalia, S., Thakur, K., Celli, A., Kiechel, M. A., and Schauer, C. L. (2013). Surface modification of plant fibers using environment friendly methods for their application in polymer composites, textile industry and antimicrobial activities: a review. J. Environ. Chem. Eng. 1, 97-112. doi: 10.1016/j.jece.2013.04.009 
Kargar, M., Wang, J., Nain, A. S., and Behkam, B. (2012). Controlling bacterial adhesion to surfaces using topographical cues: a study of the interaction of Pseudomonas aeruginosa with nanofiber-textured surfaces. Soft Matter 8, 10254. doi: 10.1039/c2sm26368h

Kasemset, S., Lee, A., Miller, D. J., Freeman, B. D., and Sharma, M. M. (2013). Effect of polydopamine deposition conditions on fouling resistance, physical properties, and permeation properties of reverse osmosis membranes in oil/water separation. J. Memb. Sci. 425-426, 208-216. doi: 10.1016/j.memsci.2012. 08.049

Kavanaugh, N. L., and Ribbeck, K. (2012). Selected antimicrobial essential oils eradicate Pseudomonas spp. and Staphylococcus aureus biofilms. Appl. Environ. Microb. 78, 4057-4061. doi: 10.1128/AEM.07499-11

Keefe, A. J., Brault, N. D., and Jiang, S. (2012). Suppressing surface reconstruction of superhydrophobic PDMS using a superhydrophilic zwitterionic polymer. Biomacromolecules 13, 1683-1687. doi: 10.1021/bm300399s

Kong, M., Chen, X. G., Xing, K., and Park, H. J. (2010). Antimicrobial properties of chitosan and mode of action: a state of the art review. Int. J. Food Microbiol. 144, 51-63. doi: 10.1016/j.ijfoodmicro.2010.09.012

Koseoglu-Imer, D. Y. (2013). The determination of performances of polysulfone (PS) ultrafiltration membranes fabricated at different evaporation temperatures for the pretreatment of textile wastewater. Desalination 316, 110-119. doi: 10.1016/j.desal.2013.02.011

Kumar, C., and Anand, S. (1998). Significance of microbial biofilms in food industry: a review. Int. J. Food Microbiol. 42, 9-27. doi: 10.1016/S01681605(98)00060-9

Kumar, R., Isloor, A. M., Ismail, A. F., and Matsuura, T. (2013a). Performance improvement of polysulfone ultrafiltration membrane using $N$-succinyl chitosan as additive. Desalination 318, 1-8. doi: 10.1016/j.desal.2013. 03.003

Kumar, R., Isloor, A. M., Ismail, A. F., and Matsuura, T. (2013b). Synthesis and characterization of novel water soluble derivative of chitosan as an additive for polysulfone ultrafiltration membrane. J. Memb. Sci. 440, 140-147. doi: 10.1016/j.memsci.2013.03.013

Kumari, A., Yadav, S. K., and Yadav, S. C. (2010). Biodegradable polymeric nanoparticles based drug delivery systems. Colloids Surf. B 75, 1-18. doi: 10.1016/j.colsurfb.2009.09.001

Lajimi, R., Ferjani, E., Roudesli, M., and Deratani, A. (2011). Effect of LbL surface modification on characterisitcs and performances of cellulose acetate nanofiltration membranes. Desalination 226, 78-86. doi: 10.1016/j.desal.2010. 08.005

Langer, R., and Tirrell, D. A. (2004). Designing materials for biology and medicine. Nature 428, 487-492. doi: 10.1038/nature02388

Lee, H., Dellatore, S. M., Miller, W. M., and Messersmith, P. B. (2007). Musselinspired surface chemistry for multifunctional coatings. Science 318, 426-430. doi: 10.1126/science. 1147241

Lee, K. Y., and Mooney, D. J. (2012). Alginate: properties and biomedical applications. Prog. Polym. Sci. 37, 106-126. doi: 10.1016/j.progpolymsci.2011. 06.003

Lichter, J. A., Thompson, M. T., Delgadillo, M., Nishikawa, T., Rubner, M. F., and Van Vliet, K. J. (2008). Substrata mechanical stiffness can regulate adhesion of viable bacteria. Biomacromolecules 9, 1571-1578. doi: 10.1021/bm $701430 y$

Liu, C. X., Zhang, D. R., He, Y., Zhao, X. S., and Bai, R. (2010). Modification of membrane surface for anti-biofouling performance: effect of antiadhesion and anti-bacteria approaches. J. Memb. Sci. 346, 121-130. doi: 10.1016/j.memsci.2009.09.028

Ma, H., Hsiao, B. S., and Chu, B. (2011). Thin-film nanofibrous composite membranes containing cellulose or chitin barrier layers fabricated by ionic liquids. Polymer 52, 2594-2599. doi: 10.1016/j.polymer.2011.03.051

Mansouri, J., Harrisson, S., and Chen, V. (2010). Strategies for controlling biofouling in membrane filtration systems: challenges and opportunities. J. Mater. Chem. 20, 4567-4586. doi: 10.1039/b926440j

Mauter, M. S., Wang, Y., Okemgbo, K. C., Osuji, C. O., Giannelis, E. P., and Elimelech, M. (2011). Antifouling ultrafiltration membranes via postfabrication grafting of biocidial nanomaterials. ACS Appl. Mater. Interfaces 3, 2861-2868. doi: 10.1021/am200522v

McCloskey, B. D., Park, H. B., Ju, H., Rowe, B. W., Miller, D. J., Chun, B. J., et al. (2010). Influence of polydopamine deposition conditions on pure water flux and foulant adhesion resistance of reverse osmosis, ultrafiltration, and microfiltration membranes. Polymer 51, 3472-3485. doi: 10.1016/j.polymer.2010.05.008

McCloskey, B. D., Park, H. B., Ju, H., Rowe, B. W., Miller, D. J., and Freeman, B. D. (2012). A bioinspired fouling-resistant surface modification for water purification membranes. J. Memb. Sci. 413-414, 82-90. doi: 10.1016/j.memsci.2012.04.021

Meel, C., Kouzel, N., Oldewurtel, E. R., and Maier, B. (2012). Threedimensional obstacles for bacterial surface motility. Small 8, 530-534. doi: 10.1002/smll.201101362

Miller, D. J., Kasemset, S., Wang, L., Paul, D. R., and Freeman, B. D. (2014). Constant flux crossflow filtration evaluation of surfacemodified fouling-resistant membranes. J. Memb. Sci. 452, 171-183. doi: 10.1016/j.memsci.2013.10.037

Mohan, T., Kargl, R., Tradt, K., Kulterer, M., Bracic, M., Hribernik, S., et al. (2015). Antifouling coating of cellulose acetate thin films with polysaccharide multilayers. Carbohydr. Polym. 116, 149-158. doi: 10.1016/j.carbpol.2014. 04.068

Ng, V. W. L., Ke, X., Lee, A. L. Z., Hedrick, J. L., and Yang, Y. Y. (2013). Synergistic co-delivery of membrane-disrupting polymers with commercial antibiotics against highly opportunistic bacteria. Adv. Mater. 25, 6730-6736. doi: 10.1002/adma.201302952

Ouattara, B., Simard, R. E., Piette, G., Bégin, A., and Holley, R. A. (2000). Inhibition of surface spoilage bacteria in processed meats by application of antimicrobial films prepared with chitosan. Int. J. Food Microbiol. 62, 139-148. doi: 10.1016/S0168-1605(00)00407-4

Palmer, J., Flint, S., and Brooks, J. (2007). Bacterial cell attachment, the beginning of a biofilm. J. Ind. Microbiol. Biot. 34, 577-588. doi: 10.1007/s10295-0070234-4

Peng, J., Su, Y., Chen, W., Zhao, X., Jiang, Z., Dong, Y., et al. (2013). Antifouling membranes prepared by a solvent-free approach via bulk polymerization of 2-hydroxyethyl methacrylate. Ind. Eng. Chem. Res. 52, 13137-13145. doi: 10.1021/ie401606a

Perera, D. H. N., Nataraj, S. K., Thomson, N. M., Sepe, A., Hüttner, S., Steiner, U., et al. (2014). Room-temperature development of thin film composite reverse osmosis membranes from cellulose acetate with antibacterial properties. J. Memb. Sci. 453, 212-220. doi: 10.1016/j.memsci.2013. 10.062

Perera-Costa, D., Bruque, J. M., González-Martín, M. L., Gómez-García, A. C., and Vadillo-Rodríguez, V. (2014). Studying the influence of surface topography on bacterial adhesion using spatially organized microtopographic surface patterns. Langmuir 30, 4633-4641. doi: 10.1021/la5001057

Reygaert, W. C. (2014). The antimicrobial possibilities of green tea. Front. Microbiol. 5:434. doi: 10.3389/fmicb.2014.00434

Rieger, K. A., Eagan, N. E., and Schiffman, J. D. (2015). Encapsulation of cinnamaldehyde into nanostructured chitosan films. J. Appl. Poly. Sci. 132, 41739. doi: 10.1002/APP.41739

Rieger, K. A., and Schiffman, J. D. (2014). Electrospinning an essential oil: cinnamaldehyde enhances the antimicrobial efficacy of chitosan/poly(ethylene oxide) nanofibers. Carbohydr. Polym. 113, 561-568. doi: 10.1016/j.carbpol.2014.06.075

Rizzello, L., Cingolani, R., and Pompa, P. P. (2013). Nanotechnology tools for antibacterial materials. Nanomedicine (Lond.) 8, 807-821. doi: 10.2217/nnm.13.63

Saeki, D., Nagao, S., Sawada, I., Ohmukai, Y., Maruyama, T., and Matsuyama, H. (2013). Development of antibacterial polyamide reverse osmosis membrane modified with a covalently immobilized enzyme. J. Memb. Sci. 428, 403-409. doi: 10.1016/j.memsci.2012.10.038

Scardino, A. J., and de Nys, R. (2011). Mini review: biomimetic models and bioinspired surfaces for fouling control. Biofouling 27, 73-86. doi: 10.1080/08927014.2010.536837

Schiffman, J. D., and Elimelech, M. (2011). Antibacterial activity of electrospun polymer mats with incorporated narrow diameter single-walled carbon nanotubes. ACS Appl. Mater. Interfaces 3, 462-468. doi: 10.1021/ am101043y

Schiffman, J. D., and Schauer, C. L. (2008). A review: electrospinning of biopolymer nanofibers and their applications. Poly. Rev. 48, 317-352. doi: $10.1080 / 15583720802022182$ 
Schiffman, J. D., and Schauer, C. L. (2009). Solid state characterization of $\alpha$-chitin from Vanessa cardui Linnaeus wings. Mater. Sci. Eng. C 29, 1370-1374. doi: 10.1016/j.msec.2008.11.006

Simoes, M., Simoes, L., and Vieira, M. (2010). A review of current and emergent biofilm control strategies. LWT-Food Sci. Technol. 43, 573-583. doi: 10.1016/j.lwt.2009.12.008

Van Houdt, R., and Michiels, C. W. (2010). Biofilm formation and the food industry, a focus on the bacterial outer surface. J. Appl. Microbiol. 109, 1117-1131. doi: 10.1111/j.1365-2672.2010.04756.x

Van Vlierberghe, S., Dubruel, P., and Schacht, E. (2011). Biopolymer-based hydrogels as scaffolds for tissue engineering applications: a review. Biomacromolecules 12, 1387-1408. doi: 10.1021/bm200083n

Wang, J., Sun, H., Gao, X., and Gao, C. (2014). Enhancing antibiofouling performance of polysulfone (PSf) membrane by photo-grafting of capsaicin derivative and acrylic acid. Appl. Surf. Sci. 317, 210-219. doi: 10.1016/j.apsusc.2014. 08.102

Wei, X., Wang, Z., Wang, J., and Wang, S. (2012). A novel method of surface modification to polysulfone ultrafiltration membrane by preadsorption of citric acid or sodium bisulfite. Memb. Water Treat. 3, 35-49. doi: 10.12989/mwt.2012.3.1.035

Xu, J., Feng, X., Hou, J., Wang, X., Shan, B., Yu, L., et al. (2013). Preparation and characterization of a novel polysulfone UF membrane using a copolymer with capsaicin-mimic moieties for improved anti-fouling properties. J. Memb. Sci. 446, 171-180. doi: 10.1016/j.memsci.2013.06.041

Zodrow, K., Schiffman, J., and Elimelech, M. (2012). Biodegradable polymer (PLGA) coatings featuring cinnamaldehyde and carvacrol mitigate biofilm formation. Langmuir 28, 13993-13999. doi: 10.1021/la303286v

Zodrow, K. R., Tousley, M. E., and Elimelech, M. (2014). Mitigating biofouling on thin-film composite polyamide membranes using a controlled-release platform. J. Memb. Sci. 453, 84-91. doi: 10.1016/j.memsci.2013.10.058

Conflict of Interest Statement: The Review Editor, James F. Holden, declares that, despite being affiliated with the same institution as authors Kerianne M. Dobosz, Kristopher W. Kolewe, Jessica D. Schiffman, the review process was handled objectively and no conflict of interest exists. The authors declare that the research was conducted in the absence of any commercial or financial relationships that could be construed as a potential conflict of interest.

Copyright (c) 2015 Dobosz, Kolewe and Schiffman. This is an open-access article distributed under the terms of the Creative Commons Attribution License (CC BY). The use, distribution or reproduction in other forums is permitted, provided the original author(s) or licensor are credited and that the original publication in this journal is cited, in accordance with accepted academic practice. No use, distribution or reproduction is permitted which does not comply with these terms. 